\title{
Para trás e entre transes: o Brasil entre Iracemas e cabras marcados à morte ou sobre uma análise fílmica de obras censuradas no decurso da ditadura militar*
}

\author{
Gabriel Bandeira Alexandre **
}

DOI: 10.11606/issn.2318-8855.v9i1p216-248

Resumo: A importância do cinema para os estudos históricos foi, e ainda é, objeto de discussão entre os historiadores, especialmente os que o reconhecem como uma fonte histórica. Considerando tal relevância à História, o objetivo deste artigo é realizar uma análise fílmica de obras que foram submetidas ao exame censório no decurso da ditadura militar brasileira, a saber: i) Terra em Transe (1967), de Glauber Rocha; ii) Iracema, uma Transa Amazônica (1976), de Jorge Bodanzky e Orlando Senna; iii) Pra Frente, Brasil (1982), de Roberto Farias; e iv) Cabra Marcado Para Morrer (1984), de Eduardo Coutinho. Para tanto, nos baseamos metodologicamente na perspectiva da História Comparada (BLOCH, 1998, p. 111-118; BARROS, 2007, 2013, p. 156-179), a qual nos permite relacionar as dimensões política, econômica, cultural e social, no contexto da ditadura militar, aos filmes selecionados, destacando as semelhanças e as diferenças entre eles e a sociedade em que estão inseridos. Assim, comparamos as produções fílmicas entre si e o regime ditatorial em questão, permitindo-nos compreender não só os filmes per se, mas também a complexidade da conjuntura durante o pós-1964.

Palavras-chave: Censura cinematográfica; Cinema; Ditadura militar.

\footnotetext{
* Agradeço ao orientador desta pesquisa Prof. Dr. Igor Lapsky da Costa Francisco, bem como ao CNPq pela concessão da bolsa de pesquisa de iniciação científica.

** Graduando do curso de Licenciatura em História pela Universidade de Pernambuco. E-mail: gabrielbandeiraa@outlook.com
} 


\section{artigos}

\section{Para trás e entre transes: o Brasil entre Iracemas e cabras marcados à morte ou sobre uma análise fílmica de obras censuradas no decurso da ditadura militar}

\section{Introdução}

Antes de tudo, é necessário destacarmos a relevância do cinema como meio de discutir e documentar, explícita ou implicitamente, questões que dizem respeito à ciência histórica e, portanto, passível de ser utilizado enquanto fonte no processo de pesquisa historiográfica. Neste sentido, nosso trabalho baseia-se nas discussões de Ferro (1992) e Rosenstone (2015), considerando que ambos nos permitem refletir acerca do cinema como uma produção humana permeada de intenções, do mesmo modo como as outras fontes utilizadas pelos historiadores.

Desse modo, não pensamos as imagens apresentadas diante da tela como obtendo um significado homogêneo, em que, de um lado, o cineasta produz e expõe ideias de modo objetivo__e em que, por outro, quem entra em contato com elas compreende-as da mesma forma. Isto é, se transpormos essa perspectiva às fontes históricas como um todo, o historiador não é um sujeito passivo diante das documentações, extraindo delas a verdade acerca dos fatos; mas, pelo contrário, é ele quem os produz, na medida em que questiona, problematiza, desconstrói e interpreta as fontes.

Levando em consideração que as fontes não transmitem a verdade ${ }^{1}$, depreendese, pois, que elas não existem fora do espaço e do tempo em que são produzidas,

\footnotetext{
${ }^{1}$ Neste debate, convém igualmente expor a contribuição de Koselleck (2006, p. 186) ao pontuar que: "toda fonte, ou mais precisamente, todo vestígio que se transforma em fonte por meio de nossas interrogações nos remete a uma história que é sempre algo mais ou algo menos que o próprio vestígio, e sempre algo diferente dele. Uma história nunca é idêntica à fonte que dela dá testemunho. Se assim fosse, toda fonte que jorra cristalina seria já a própria história que se busca conhecer". Cf. também Napolitano (2008, p. 235-289), especialmente a diferenciação que ele realiza acerca do cinema na
} 


\section{artigos}

\section{Gabriel Bandeira Alexandre}

permitindo-nos afirmar que são geradas por meio dos objetivos de quem as cria. Dessa forma, considerar o cinema como fonte, é compreendê-lo como produto humano inserido em um contexto no qual os "cineastas, conscientemente ou não, estão cada um a serviço de uma causa, de uma ideologia, explicitamente ou sem colocar abertamente as questões" (FERRO, 1992, p. 14). Neste sentido, a linguagem cinematográfica, assim como qualquer outra, não é ingênua, sendo a história e o cinema invenções humanas subjetivamente orientadas ${ }^{2}$ e que produzem ideias e, igualmente, são erigidas por ideias.

Isto posto, salientemos o nosso recorte espaço-temporal: o mais recente período ditatorial brasileiro (1964-1985). Neste, os militares com a ajuda direta e indireta de uma parcela da sociedade $\mathrm{civil}^{3}$, se baseavam, dentre outras formas de violência, na eliminação da liberdade de expressão através da censura, a qual atingia, para além do âmbito das Diversões Públicas e da Imprensa, também as pessoas envolvidas em tais produções. Dessa maneira, os militares demonstravam, por um lado, que tinham força; mas, por outro, eram fracos, pois se se utilizavam de tal prática, era porque reconheciam o potencial de transformação que as ideias poderiam causar, especificamente aquelas antagônicas à ditadura.

Nesta relação de forças, cabe ressaltar a análise de Bresciani $(2004$, p. 11) ao, a partir das teses de Hannah Arendt, considerar a imposição do silêncio ao outro como o fim da política, tendo em vista que esta se relaciona com o debate de ideias e não com o silêncio. Por essa razão, os sucessivos governos militares, ao negarem a livre

\footnotetext{
História, da história no cinema e a História do cinema.

${ }^{2} \mathrm{O}$ que não significa, de forma alguma, que a história é construída de qualquer maneira, pois o ofício de historiador necessita de um embasamento tanto teórico quanto metodológico.

${ }^{3}$ Para uma análise da relação entre militares e civis no período pré-Golpe civil-militar e durante a ditadura, cf. Dreifuss (1981), Fico (2014) e Napolitano (2017).
} 


\section{artigos}

Para trás e entre transes: o Brasil entre Iracemas e cabras marcados à morte ou sobre uma análise fílmica de obras censuradas no decurso da ditadura militar

circulação de pensamento, estavam eliminando o exercício da política e da liberdade, privilegiando a ação coercitiva.

De acordo com Napolitano (2017, p. 99), o regime era formado por um tripé repressivo, a partir: 1) das Delegacias de Ordem Política e Social (DOPS); 2) do Destacamento de Operações e Informações - Centro de Operações de Defesa Interna (DOI-CODI); e 3) da Divisão e Serviços de Censura de Diversões Públicas/Departamento de Polícia Federal (SCDP e DCDP/DPF). Neste sentido, consideramos, assim como sugere tal historiador, os órgãos de censura relacionados a outras instituições, as quais, para além da censura, produziam informações, controlavam e vigiavam, objetivando, no âmbito cultural, criar suspeitas e impor silêncio.

Tendo por base tais pontos, selecionamos quatro filmes produzidos entre as décadas 1960 e 1980, a saber: a) Terra em Transe (1967), de Glauber Rocha; b) Iracema, uma Transa Amazônica (1976), de Jorge Bodanzky e Orlando Senna; c) Pra Frente, Brasil (1982), de Roberto Farias; e d) Cabra Marcado Para Morrer (1984), de Eduardo Coutinho. Convém ressaltar que a escolha de tais obras decorre não só dos problemas discutidos pelos filmes, cuja importância está associada a questões que atravessam as dimensões política, econômica e social do período, mas também das maneiras pelas quais cada uma aborda estes pontos.

Dessa forma, primeiramente apresentamos e relacionamos as fontes fílmicas, assim como as formas pelas quais elas foram censuradas, discutindo as heterogeneidades no tocante à atuação censória - aqui considerada enquanto uma ação violenta cujo objetivo é o impedimento do dissenso, qual seja, as oposições 


\section{artigos}

\section{Gabriel Bandeira Alexandre}

potenciais ${ }^{4}$. Posteriormente, efetuamos as análises dos filmes mediante duas categorias analíticas ao relacionarmos os filmes à Democracia e à Violência 5 . Em vista disso, refletimos sobre o porquê das obras de Rocha, Bodanzky e Senna, Farias e Coutinho terem sido censuradas, bem como sobre a relevância de tais produções no debate sobre temáticas que os militares pretendiam ocultar e/ou tratar de tal modo que beneficiassem a ditadura.

\section{Trajetórias dos filmes diante da censura cinematográfica}

Mediante uma seleção baseada na ordem crescente de lançamento, destacamos primeiramente Terra em Transe (1967), de Glauber Rocha ${ }^{6}$, um drama cuja história gira em torno do país Eldorado, marcado por problemas sociais, econômicos e políticos, e de personagens como a militante Sara, o jornalista e poeta Paulo Martins, além dos políticos Porfírio Diaz e Felipe Vieira, servindo enquanto metáfora às questões não só da sociedade brasileira, como também da América Latina, submersa em um processo de transe político. Esta obra, lançada no período pré-Al-5, sob o governo do general Costa e Silva (1967-1969), é uma das que melhor representa o momento de superpolitização da cultura à esquerda no Brasil (1964-1968), como sugere Ridenti (2014, p. 241), cujas brechas concedidas a algumas produções culturais caminhavam ao lado

\footnotetext{
${ }^{4}$ Ressaltamos que não faz parte dos objetivos deste artigo realizar uma discussão conceitual acerca da censura. Cumpre, todavia, destacar que apoiamo-nos nas perspectivas de Leonor Pinto (2005; 2006), Beatriz Kushnir (2004), Meize Lucas (2015a; 2015b; 2015c), Inimá Simões (1999) e Creuza Berg (2002), ao consideramos tal ato para além da interdição e sempre como politicamente orientado.

${ }^{5}$ Cumpre frisar que a seleção destas categorias de análise, assim como ocorreu com a seleção fílmica, relaciona-se com temáticas caras à época que, no entanto, não poderiam ser discutidas de qualquer maneira.

${ }^{6}$ Glauber de Andrade Rocha (1939-1981) foi um cineasta e escritor brasileiro, nascido na Bahia, e um dos principais integrantes do movimento Cinema Novo. Dentre suas produções cinematográficas, destacamos Deus e o Diabo na Terra do Sol (1964), O Dragão da Maldade contra o Santo Guerreiro (1968), Di-Glauber (ou Di Cavalcanti), de 1977, e A Idade da Terra (1980); dentre as escritas, Revisão crítica do cinema brasileiro (1963), Riverão Sussuarana (1978) e Revolução do Cinema Novo (1981).
} 


\section{artigos}

\section{Para trás e entre transes: o Brasil entre Iracemas e cabras marcados à morte ou sobre uma análise fílmica de obras censuradas no decurso da ditadura militar}

da derrota dos projetos políticos das esquerdas. Especialmente por essa razão, este espaço de tempo é por vezes ainda referido como brando, desconsiderando que todos os filmes exibidos só o foram depois de serem submetidos à censura prévia (GASPARI, 2014b, p. 133; NAPOLITANO, 2017, p. 69; RIDENTI, 2014, p. 233).

É neste sentido que o filme de Glauber será interditado em todo o território nacional ao ser considerado altamente subversivo por versar acerca de problemas como a fome, a luta com uso da violência por melhores condições de vida e a não laicidade do Estado, além do fato de conter cenas lésbicas ${ }^{7}$. Depois de debates, como o ocorrido no Museu da Imagem e do Som do Rio de Janeiro; protestos, como o telegrama enviado ao presidente, por alguns artistas europeus, solicitando a liberação do filme; e, por fim, a exigência de o padre recebesse um nome, a obra foi liberada sem cortes (SIMÕES, 1999, p. 93).

\footnotetext{
7 Tais considerações foram verificadas em algumas documentações de censura encontradas em 2018, antes do Projeto Memória da Censura no Cinema Brasileiro (http://memoriacinebr.com.br), o qual continha um acervo de arquivos relacionados à atuação censória ao cinema durante a ditadura militar, sair do ar:

Elaboração Portaria (pedido de interdição) assinado por Antônio Romero Lado, chefe do SCDP, de 19 de abril de 1967. Ministério da Justiça e Negócios Interiores - Departamento Federal de Segurança Pública; Parecer 13408/74, assinado por Therezinha de Toledo Neves e Edite Kazuko Nakashoji, de 4 de março de 1974. Ministério da Justiça - Divisão de Censura de Diversões Públicas;

Parecer do filme assinado pela chefa da turma de censura cinematográfica, Jacira Oliveira, de 18 de abril de 1967. Ministério da Justiça e Negócios Interiores - Departamento Federal de Segurança Pública;

E Portaria No 16/67 - SCDP (decisão de interdição), por Antônio Romero Lago, de 19 de abril de 1967. Ministério da Justiça e Negócios Interiores - Departamento Federal de Segurança Pública/Serviço de Censura de Diversões Públicas.

Ademais, Glauber Rocha era considerado principal seguidor do cineasta Godard e suas obras eram consideradas um estímulo à subversão, como afirmava o consultor em análise de técnicas cinematográficas, Waldemar de Souza (SIMÕES, 1999, p. 147-152).
} 


\section{artigos}

\section{Gabriel Bandeira Alexandre}

Foi censurado na década seguinte, em 1976, época do governo Geisel e da abertura política, o filme teuto-brasileiro Iracema, uma Transa Amazônica, uma realização de Jorge Bodanzky ${ }^{8}$ e Orlando Senna ${ }^{9}$ sob encomenda da emissora alemã Zweites Deutsches Fernsehen (ZDF). Ambientada em 1974 na região Amazônica e misturando aspectos ficcionais a documentais (docudrama), a obra, por meio da história da prostituta Iracema, com 15 anos de idade, e sua relação com o caminheiro chamado Tião, expõe as consequências desagradáveis da Rodovia Transamazônica ${ }^{10}$, considerada como uma construção que contribuiria para o desenvolvimento do país. Por contrariar a propaganda oficial e positiva do governo Médici (1969-1974) ${ }^{11}$, além de ser considerada uma produção estrangeira, o filme tem uma trajetória de interdição diferente da de Terra em Transe diante da censura, obtendo liberação só em 1981 (SIMÕES, 1999, p. 203; DIAS JUNIOR, 2013, p. 4).

\footnotetext{
${ }^{8}$ Jorge Bodanzky (1942, São Paulo) é um cineasta e fotógrafo brasileiro, conhecido por suas obras que mesclam ficção e documentário, bem como por tratarem de temáticas relacionadas à Amazônia. Alguns de seus filmes são Gitirana (1975), Os Mucker (1978), Terceiro Milênio (1980) e Era uma vez Iracema (2005). Seus trabalhos também se vinculam à academia, tendo sido professor da ECA/USP, da FAAP, da UNICAMP e da UNB. Convém ainda destacar que em 2017, foi lançado seu livro Procurando Iracema.

${ }^{9}$ Orlando Sales de Senna (1940, Bahia) é um cineasta, escritor e jornalista brasileiro, responsável pela direção de películas como Gitirana (1975), Ilé Aiyé Angola (1986) e Brascuba (1987). Dentre seus escritos, pontuamos Alberto Santos Dumont: ares nunca dantes navegados (1984) e Os lençóis e os sonhos: romance (2009).

${ }^{10}$ Vinculado ao Programa de Integração Nacional (PIN), o projeto em torno da Transamazônica/BR-230 (1972), que ligaria o Maranhão ao Acre, faz parte das intituladas obras faraônicas do governo militar, cuja construção resolveria, de acordo com Médici, o problema da Amazônia, vista como terra sem homens; e o do Nordeste, considerado um lugar com muitos homens sem terra. Dessa forma, seriam enviados nordestinos à região amazônica com o intuito de promover o povoamento e consequente desenvolvimento desta área. Contudo, a obra ainda mantém-se inacabada, sem ter estimulado, portanto, o progresso que a propaganda oficial disseminou (SKIDMORE, 1988, 287-295).

${ }^{11} \mathrm{O}$ funcionamento da propaganda em tal período está vinculado à Assessoria Especial de Relações Públicas (AERP), criada em 1968 sob o comando do coronel Octavio Costa, a qual objetivava centralizar a atuação propagandística em torno do governo militar e, desse modo, legitimá-lo e eliminar informações que envolvessem aspectos negativos da sociedade brasileira (SKIDMORE, 1988, p. 221).
} 


\section{artigos}

\section{Para trás e entre transes: o Brasil entre Iracemas e cabras marcados à morte ou sobre uma análise fílmica de obras censuradas no decurso da ditadura militar}

No momento em que a abertura política estava mais avançada em alguns termos, com a conquista da Anistia e o funcionamento do Conselho Superior de Censura $(\mathrm{CSC})^{12}$, em 1979, por exemplo, a censura ainda se manifestava de modo rigoroso. Isso fica claro em 1982, com Pra Frente, Brasil, do cineasta e ex-diretor da Embrafilme Roberto Farias ${ }^{13}$. O drama, ambientado no Brasil de junho dos anos 1970, época da Copa do Mundo, exibe, a partir do personagem Jofre, a violência repressiva do Estado ditatorial de maneira explícita, a qual recebia financiamento de importantes empresários. Assim, a obra inicialmente liberada pelos censores, foi posteriormente interditada mediante acusação de contrariar o regime vigente pela chefa da DCDP Solange Hernandes, conhecida por seu viés mais conservador no âmbito da censura, responsável, também, por esconder pareceres favoráveis à liberação do filme. Este só foi liberado em dezembro do mesmo ano, depois de ser analisado pelo CSC (SIMÕES, 1999, p. 238; PADULA LAMAS, 2015, p. 15; GUEDES, 2016, p. 145).

E para encerrar as considerações acerca da atuação censória sobre os quatro filmes, trataremos, pois, do documentário Cabra Marcado Para Morrer (1984), de

\footnotetext{
12 Órgão criado pela Lei $n^{\circ}$ 5.536, conhecida como nova lei de censura, por meio do Art. 15, o qual estava subordinado ao Ministério da Justiça e era responsável por rever as decisões, emitidas pelo diretor-geral do Departamento de Polícia, concernentes à censura às diversões públicas e aos espetáculos (Art. 17). Legislação Informatizada - Lei $n^{\circ}$ 5.536, de 21 de novembro de 1968 - Publicação Original. Disponível em: $\quad$ https://www2.camara.leg.br/legin/fed/lei/1960-1969/lei-5536-21-novembro-1968-357799publicacaooriginal-1-pl.html>. Acesso em: 28 jul. 2019.

Cf. também Albin (2002).

${ }^{13}$ Roberto Figueira de Farias (1932-2018) foi um cineasta brasileiro nascido no Rio de Janeiro e importante na produção não só de filmes (Assalto ao Trem Pagador, de 1962; Roberto Carlos a 300 Quilômetros Por Hora, de 1971; e Os Trapalhões no Auto da Compadecida, de 1987), como também de minisséries (A Máfia no Brasil, de 1984, e As Noivas de Copacabana, de 1992) e programas para televisão (Sob Nova Direção, de 2004 a 2007).
} 


\section{artigos}

\section{Gabriel Bandeira Alexandre}

Eduardo Coutinho ${ }^{14}$ e vinculado ao Centro Popular de Cultura da União Nacional dos Estudantes (CPC da UNE), cujo percurso censório é uma exceção diante não só das obras aqui elencadas, mas também de outras tantas censuradas. Isso decorre do fato de que a produção, de 1964, foi interrompida nos primeiros momentos da ditadura, impossibilitando que um documento oficial de censura pudesse ser elaborado, vide a inexistência do filme para tal ato. Neste aspecto, consideramos que a censura, aliada à repressão policial sobre os envolvidos, atingiu o processo de realização fílmica no Engenho Galileia, em Vitória de Santo Antão (PE), local das gravações. Acerca disso, observamos na edição do dia 7 de abril de 1964 do Diario de Pernambuco que o local foi considerado como o maior foco de subversão comunista no interior de Pernambuco; e os materiais referentes ao filme, por sua vez, enquanto subversivos, a fim de executar um perfeito plano subversivo e terrorista no Estado ${ }^{15}$. Desse modo, o filme foi considerado contrário ao regime que estava se instaurando, incentivando-nos afirmar, a partir do distanciamento de perspectivas que avaliam a violência mediante critérios quantitativos, que desde o início o que estava ocorrendo não era nada moderado e Cabra demonstra isso.

Com o processo de produção retomado na década de 1980, temos uma película que, se antes pretendia tratar sobre a história do líder das Ligas Camponesas de Sapé (PB), João Pedro Teixeira, assassinado em 1962 pela polícia, tornou-se um filme que

\footnotetext{
${ }^{14}$ Eduardo de Oliveira Coutinho (1933-2014) foi um cineasta brasileiro nascido em São Paulo, responsável, especialmente, pela produção de documentários e reconhecido como um dos principais documentaristas do país. Dentre suas obras, sublinhamos Faustão (1971), Seis Dias em Oricuri (1976, produzido para o programa Globo Repórter da TV Globo), Santo Forte (1999), Babilônia 2000 (2000) e Edifício Master (2002).

15 DIARIO DE PERNAMBUCO, Recife, n. 79 - ano 139, 7 de abril de 1964. Disponível em: $<$ http://memoria.bn.br/DocReader/docreader.aspx?bib=029033_14\&pasta=ano\%20196\&pesq=marcado s\%20para\%20morrer>; e em: <http://memoria.bn.br/DocReader/docreader.aspx?bib=029033_14\&pasta=ano\%20196\&pesq=marcado s\%20para\%20morrer>. Acesso em: 13 out. 2019.
} 


\section{artigos}

Para trás e entre transes: o Brasil entre Iracemas e cabras marcados à morte ou sobre uma análise fílmica de obras censuradas no decurso da ditadura militar

exibe, além disso, a violência exercida pelos militares durante a ditadura. Neste sentido, Coutinho, ao reencontrar as pessoas que fizeram parte das primeiras filmagens possibilita-nos entrar em contato com as lembranças traumáticas dos personagens inseridos em um contexto no qual a luta camponesa estava associada à prática subversiva. Desse modo, temos um filme que trata tanto dos desdobramentos do regime militar, mediante relatos de pessoas como Elizabeth Teixeira, quanto dele mesmo, tendo em vista que o ocorrido com os personagens no pós-1964 está diretamente ligado à produção de Cabra. Por fim, em 1984, a obra foi liberada apenas com restrição para menores de 18 anos, em razão das cenas de violência ${ }^{16}$.

Dito isso, notamos que tais filmes se ligam em determinados aspectos, principalmente por contrariarem alguns discursos defendidos pelos governos militares, como o da existência de uma democracia sob um contexto marcado pelo progresso socioeconômico cujos benefícios atingiam a todos, e de que o Brasil caminhava para a superação do seu subdesenvolvimento; e, por isso, seria dispensável a exposição de que o Estado ditatorial recorria ao uso da coerção para eliminar discordâncias aos seus projetos, algo que não foi efetivamente possível. É pela necessidade de discutir a forma como essas obras expuseram essas questões que iremos nos deter a partir desse momento na análise fílmica.

\section{Categoria I: Democracia}

\footnotetext{
${ }^{16}$ Certificado n ${ }^{\circ}$ A - 13706, de 6 de novembro de 1984. Departamento de Polícia Federal - Divisão de Censura de Diversões Públicas (DPF/DCDP). Este certificado também não está mais disponível no site em que foi encontrado, mas cumpre ressaltar que o salvamos do http://memoriacinebr.com.br/, em 2018.
} 


\section{Gabriel Bandeira Alexandre}

Esta é uma categoria que está presente em todos os filmes em graus variados, no entanto, se levarmos em consideração a concepção de democracia discutida por Bobbio (1998, p. 319), temos de um lado a formal e de outro a substancial, em que aquela diz respeito ao governo do povo; e esta, para o povo. Ao desconsiderar a existência de uma democracia em estado de perfeição, o filósofo pontua que cada um compreende como democrático o sentido que é de sua defesa, bem como entende como não democrático o que se distancia deste significado defendido (BOBBIO, 1998, p. 328). Sob tal perspectiva, a democracia assume mais de um sentido, permitindo-nos questionar quem é todo esse povo ${ }^{17}$ que as democracias pretendem beneficiar.

É partindo de tal premissa que destacamos a existência da noção entre os governos militares de que o regime que se instaurou era fruto de uma revolução que tinha caráter democrático e representativo ${ }^{18}$. Neste aspecto, todos esses filmes oferecem-nos um questionamento a essa denominação, pois apresentam problemas da sociedade brasileira que a distanciam de um regime democraticamente instituído,

\footnotetext{
${ }^{17}$ Para um debate em torno do sentindo político de tal conceito, ver a análise de Paolo Colliva, em Bobbio (1998, p. 986-987). A partir disso, neste trabalho, adotaremos o sentido que compreende o povo enquanto sujeito político, mas que constantemente era afastado do centro das decisões políticas, isto é, o oprimido.

${ }^{18}$ Isto se percebe, por exemplo: a) na Constituição de 1967, cuja palavra democrático/a é mencionada 4 vezes, vide o Inciso I, dos Arts. 148 e 149; o Art. 151; e o $\S 2^{\circ}$, do Art. 166. Disponível em: <http://www.planalto.gov.br/ccivil_03/constituicao/constituicao67.htm>. Acesso em: 13 jul. 2019;

$\mathrm{E}$ b) no Al-5 de 1968, cujo primeiro Considerando tem os seguintes dizeres: "CONSIDERANDO que a Revolução Brasileira de 31 de março de 1964 teve, conforme decorre dos Atos com os quais se institucionalizou fundamentos e propósitos que visavam a dar ao País um regime que, atendendo às exigências de um sistema jurídico e político, assegurasse autêntica ordem democrática, baseada na liberdade, no respeito à dignidade da pessoa humana, no combate à subversão e às ideologias contrárias às tradições de nosso povo, na luta contra a corrupção, buscando, deste modo, 'os meios indispensáveis à obra de reconstrução econômica, financeira, política e moral do Brasil, de maneira a poder enfrentar, de modo direito e imediato, os graves e urgentes problemas de que depende a restauração da ordem interna e do prestígio internacional da nossa pátria' (Preâmbulo do Ato Institucional $n^{\circ} 1$, de 9 de abril de 1964)". Disponível em: <http://www.planalto.gov.br/ccivil_03/AIT/ait-05-68.htm>. Acesso em: 13 jul. 2019.
} 


\section{artigos}

Para trás e entre transes: o Brasil entre Iracemas e cabras marcados à morte ou sobre uma análise fílmica de obras censuradas no decurso da ditadura militar

inclusive no não respeito a um princípio essencial: que a escolha dos governantes teria que ser fruto da escolha da população (SILVA, 2009, p. 89), apesar do apoio de parte desta à ditadura.

Em Terra em Transe, percebemos o debate em torno do ideal democrático pela presença de políticos com viés populista, que prometiam melhores condições de vida à população miserável de Alecrim e Eldorado, e que todavia, não cumpriam por fatores como a relação deles com grandes proprietários de terras, os quais são relevantes na política brasileira ao financiar eleições de determinados chefes políticos, com interesses conflitantes com os do povo, este uma figura tão presente nas falas de candidatos. Isso é exposto no momento em que o governador da província de Alecrim, Felipe Vieira, não se contrapõe ao responsável pela morte do camponês Felício, haja vista sua ligação, sobretudo econômica, com o coronel Moreira, o autor do crime. Dessa forma, embora Vieira, valendo-se de um princípio democrático, permita protestos afirmando que todos tem o direito de protestar, em consequência da morte de Felício não pretende produzir conflito com um aliado político, mesmo que este seja um algoz às massas, estas que lhes garantiram estar governando.

Outro importante personagem no tocante à democracia é Porfirio Diaz, o senador de Eldorado, cujo nome faz alusão a um militar mexicano, imbuído de um catolicismo excessivo, o qual se reflete em sua dificuldade de separar os aspectos referentes ao que é público daquilo que deve ser governado na esfera privada. Este personagem, empunhando uma bandeira preta e um crucifixo em suas mãos, ao mencionar em tom autoritário o que era a democracia, afirma ser o exercício da vontade 


\section{artigos}

\section{Gabriel Bandeira Alexandre}

do povo, confirmando, além disso, seu compromisso com a pátria e a família. É diante dessa alusão às proximidades entre Estado e Igreja que Diaz afirma que dominará Eldorado, objetivando ordenar as tradições histéricas com o uso da força, por seu amor à força.

A partir do Golpe de Estado comandado por Diaz, o filme proporciona-nos uma reflexão acerca da concepção de democracia que os governos militares sustentavam durante o pós-Golpe civil-militar, cujo sentido tentavam associar à ideia de uma revolução, totalmente desvinculada, na prática, da necessária transformação radical na estrutura da sociedade brasileira. Mediante isso, esse personagem se coaduna aos presidentes militares, os quais se utilizavam de um discurso em que o funcionamento da democracia do governo revolucionário precisaria conviver com a conservação das tradições que estavam desordenadas, por intermédio da coerção. Antidemocraticamente, o ditador de Eldorado, assim como os ditadores do Brasil, não estava preocupado com mudanças nem com o povo, este visto como burro, mas, por outro lado, com a sua manutenção no poder, guiando a população através de sua vontade sendo imposta - desejo não totalmente alcançado.

Iracema, Uma Transa Amazônica, por seu turno, permite-nos discutir sobre a democracia de um modo diferente, tendo em vista que o termo não aparece explicitamente na obra, como observamos na anterior. Dessa forma, notamos, por meio da imagem amazônica apresentada, os limites do governo que se dizia democrático baseado em uma retórica que defendia investimentos sociais para o desenvolvimento do Brasil (SKIDMORE, 1988, p. 278). Na prática, esses investimentos eram escassos, o que pode ser conferido nas imagens que Bodanzky e Senna gravam, em 1974, na região da Transamazônica, em que vemos um lugar que se pretendia ser um símbolo de desenvolvimento, mas que, contrariamente, representava a miséria. 


\section{artigos}

Para trás e entre transes: o Brasil entre Iracemas e cabras marcados à morte ou sobre uma análise fílmica de obras censuradas no decurso da ditadura militar

Assim, problemas que existiam anteriormente, são acentuados com a construção da BR-230, como a falta de oportunidades de trabalho que estimulavam a prostituição infantil de meninas, além das desigualdades que podem ser percebidas, por exemplo, através da contraposição de imagem entre palafitas de um lado e prédios, de outro (GOTTWALD JUNIOR, 2016, p. 53). É neste sentido, portanto, que essa produção conduznos à reflexão acerca de qual povo o governo militar representava democraticamente que, em vez de frear as diferenciações socioeconômicas, intensificava-as.

Em Pra Frente, Brasil, semelhante à Iracema no tocante a não explanação da palavra democracia, vemo-la ser contestada em uma cena na qual o torturado Jofre, confundido pelos militares com um militante à esquerda e sequestrado por estes, indaga "Com que direito, meu Deus?" e "E os meus direitos?". Estes questionamentos, realizados distante de seus algozes, demonstram que essa democracia da retórica militar não respeitava a liberdade e a dignidade humanas, mesmo em seu caso, vide seu não engajamento político, se intitulando enquanto neutro e apolítico. Em vista disso, Jofre elenca alguns deveres de homem comum que estava cumprindo, tais como o pagamento de impostos, bem como sua condição de empregado, pai e marido, concluindo que ninguém tinha o direito de submetê-lo a tal situação. Contudo, respeito e combate se conflitavam ${ }^{19}$, de sorte que a dignidade e liberdade humanas eram garantias que atingiam apenas alguns, especialmente os que não eram vistos como subversivos.

\footnotetext{
${ }^{19}$ Aqui relacionamos os atos de respeitar e combater com base no $\mathrm{Al}-5$, em que o respeito à dignidade da pessoa humana aparece ao lado do combate à subversão e às ideologias contrárias ao regime em questão.
} 


\section{artigos}

\section{Gabriel Bandeira Alexandre}

Cabra Marcado Para Morrer, por fim, é o filme em que a análise sobre a democracia aparece em sua forma mais potente e escancarada, mediante as palavras de Elizabeth Teixeira, principalmente. Para tal ponto, recorreremos à sua fala ao se despedir de Eduardo Coutinho, nos momentos finais do filme. A matriarca da família Teixeira assume que precisou recuar em sua luta devido à vida na clandestinidade com a instauração da ditadura, mas que, a partir de então, iria continuar lutando por melhores condições de vida. Em seus dizeres, percebemos que o regime do pós-1964 ocasionou regressos em sua situação, haja vista que a mesma necessidade de 64 ainda estava imposta ao operário, ao camponês e ao estudante, submetidos à fome e a baixos salários. Partindo disso, Elizabeth questiona explicitamente a democracia ao intitulá-la de regimezinho e democraciazinha, expondo as suas insuficiências para o povo $^{20}$.

Apesar de sua crítica ao regime, Elizabeth se refere, tanto no início quanto durante os últimos minutos do filme, ao contexto em questão com esperança quando menciona o presidente João Baptista Figueiredo (1979-1985) em tom de agradecimento por lhe possibilitar o reencontro com pessoas que há tempos não tinha contato, oportunidade que se coadunava ao desenvolvimento da redemocratização brasileira na década de 1980. Neste sentido, ao mesmo tempo em que Elizabeth reconhece este aspecto positivo, sua retórica não se furta em evidenciar as continuidades

\footnotetext{
${ }^{20} \mathrm{Com}$ algumas supressões que não interferem no sentido da fala de Elizabeth, transcrevemo-la: "A luta é que não para! A mesma necessidade de 64 está plantada! Ela não fugiu um milímetro! A mesma necessidade tá plantada na fisionomia do operário, do homem do campo e do estudante. A luta é que não pode parar! Enquanto se diz tem fome e salário de miséria, o povo tem que lutar! Quem é que não luta por melhores dias de vida? Tem que lutar! Quem tem condições, quem tiver sua boa vida que fique aí, né?! Eu, como venho sofrendo, eu tenho que lutar até hoje e tenho peito de dizer: é preciso mudar o regime, é preciso que o povo lute! Enquanto tiver esse regimezinho, essa democraciazinha aí... Democracia sem liberdade? Democracia com salário de miséria e de fome? Democracia com o filho do operário e do camponês sem ter direito a estudar?".
} 


\section{artigos}

Para trás e entre transes: o Brasil entre Iracemas e cabras marcados à morte ou sobre uma análise fílmica de obras censuradas no decurso da ditadura militar

intensificadas com os anos de ditadura. Dessa forma, por ser do gênero documental, em Cabra, diferente de todos os três filmes acima, a democracia aparece com referências mais diretas à situação do Brasil, em que a protagonista associa transformação à luta política, permitindo-nos retomar o pensamento de Bobbio quando este destaca que a democracia perfeita seria a junção entre a formal e a substancial, constituindo um governo que seria do povo e para o povo, simultaneamente (BOBBIO, 1998, p. 329). Relacionando o pensamento deste filósofo ao de Elizabeth, somos orientados a refletir em torno da ideia de que mediante a luta haveria mudanças efetivas, contribuindo para a gestação de outro regime cujos princípios democráticos se estenderiam a todas as pessoas ${ }^{21}$.

\section{Categoria II: Violência}

Se neste artigo atribuímos à ação censória um sentido de violência, não poderíamos alhear-nos, igualmente, de sua presença nos filmes e que na ditadura funcionou como uma regra e não só por parte dos militares, como também por alguns civis, embora seus usos possuam finalidades diversas. Considerando tal ponto, recorremos à ideia de Stoppino (1998, p. 1291) acerca da violência, cuja análise propõe que ela se constitui enquanto tal a partir do momento em que se utiliza voluntariamente a força física, a fim de coagir, ofender e destruir.

Diante disso, ultrapassaremos a qualidade física da violência, compreendendo-a também como um ato que impede o outro de realizar determinada atividade ou o

\footnotetext{
${ }^{21}$ Para mais debates acerca da obra, ver as dissertações de mestrado de Queiroz (2005) e Harris (2008).
} 


\section{artigos}

\section{Gabriel Bandeira Alexandre}

impede de ter acesso a certos recursos materiais. Neste sentido, seu uso provoca sempre uma alteração prejudicial do estado físico do outro o qual se pretende violentar. Não pretendemos, pois, utilizar o termo de modo desorientado, em que tudo se torna violência, incorrendo no esvaziamento do conceito. No entanto, para a realização do nosso objetivo, a categoria violência operará tanto mediante seu caráter físico quanto de relações de poder coercitivo (STOPPINO, 1998, p. 1292).

Ao discutir a violência em Terra, é necessário frisar que Glauber Rocha foi influenciado pelo contexto de movimentos sociais e revoluções da segunda metade do século XX, o que fica explicitado na sua percepção de que mediante a cultura da fome, manifestada com o uso da violência associada ao amor às transformações sociais, seria superada a situação de miserabilidade social presente na América Latina ${ }^{22}$. Desde o início do filme, notamos tal elemento, especialmente quando, simbolizando a Primeira Missa no Brasil (1500) em uma praia, aparecem o colonizador europeu, o clérigo e Porfirio Diaz - símbolos da coerção - em direção ao indígena que se encontrava em terra antes da invasão. Dessa forma, a violência se estabelece enquanto um ato que faz parte da fundação do Brasil, assim como a censura (KUSHNIR, 2004, p. 35).

Embora a figura dos políticos seja a representação máxima do uso da violência contra o povo, apontaremos sua relação com o jornalista Paulo Martins, representante do intelectual ${ }^{23}$ e militante à esquerda que se torna um desiludido no que concerne à política, tendo em vista que seu funcionamento ocorria por meio de alianças ora com

\footnotetext{
${ }^{22}$ Ao afirmar, em Eztetyka da Fome (1965), que o comportamento de um faminto é a violência, Rocha pontua que "uma estética da violência antes de ser primitiva é revolucionária, eis aí o ponto inicial para que o colonizador compreenda a existência do colonizado: somente conscientizando sua possibilidade única, a violência, o colonizador pode compreender, pelo horror, a força da cultura que ele explora. Enquanto não ergue as armas o colonizado é um escravo: foi preciso um primeiro policial morto para que o francês percebesse um argelino" (ROCHA, 1981, p. 28-33). Cf. também: XAVIER (2001, p. 117-146). ${ }^{23}$ Para uma discussão acerca do papel do intelectual em Terra em Transe, ver: VIANA (2011).
} 


\section{artigos}

\section{Para trás e entre transes: o Brasil entre Iracemas e cabras marcados à morte ou sobre uma análise fílmica de obras censuradas no decurso da ditadura militar}

fazendeiros, como no de Felipe Vieira, ora com empresários e empresas representantes do imperialismo norte-americano, a exemplo de Júlio Fuentes e da Explint, respectivamente. Inserido em uma situação extrema, o poeta junto à militante Sara, com uma arma em mãos, demonstra, depois de suas esperanças fracassadas quando do apoio a líderes corruptos e do Golpe, sua opção pela luta armada, a fim de destruir as injustiças existentes e, assim, iniciar a história. Essa obra de 1967 dialoga, neste aspecto, com o contexto brasileiro da época, no qual alguns civis escolheram as vias armadas para tentar derrubar o regime imposto, se utilizando da violência enquanto reação aos abusos de poder dos governantes (GASPARI, 2014c, p. 239). A opção pelo uso das armas, assim, seria igualmente a expressão de uma luta pelo povo sem a presença dele, haja vista a ideia de que o povo era inconsciente de sua própria condição de miséria, necessitando, pois, da orientação não só de políticos, mas também dos intelectuais (GASPARI, 2014a, p. 467).

Além da violência contra o povo, explicitada no filme anterior, percebemos sua manifestação também contra a natureza e as mulheres em Iracema, quando observamos o desmatamento das árvores e a exploração sexual de meninas e mulheres na região amazônica. Assim como em Terra, a obra demonstra a presença de investidores na política, cuja retórica tende a se distanciar da prática, aspecto notório no que tange também aos políticos quando discutimos acerca da democracia no tópico anterior. Tal aspecto é representado durante a conversa entre um negociante e Antônio, um morador da região, na qual aquele, ao mesmo tempo em que diz se preocupar com a ecologia, também demonstra despreocupação no tocante às questões ecológicas e desprezando os possíveis prejuízos ambientais, em razão da 


\section{artigos}

\section{Gabriel Bandeira Alexandre}

possibilidade de emprego que seria oferecido a 6 mil pessoas que estariam envolvidas na construção da Transamazônica. Ademais, a personagem Iracema representa a história de muitas outras meninas que estavam submetidas à prostituição, permeada de violência psicológica e física (GOTTWALD JUNIOR, 2016, p. 22).

Mesmo que tenhamos destacado a mulher e a natureza, o filme permite-nos pensar, além disso, nas populações indígenas historicamente submetidas a diversos tipos de violências. Em Iracema vinculamos isso a três pontos: i) a escolha de Edna de Cássia, de origem indígena, para realizar o papel de protagonista; ii) a opção por Iracema como nomes tanto para a personagem, remetendo à indígena da obra de José de Alencar com o mesmo título, quanto para o filme; e iii) a fala do caminhoneiro Tião ao afirmar que cruzava a rodovia antes mesmo de sua existência, época em que havia até perigo de índio, possibilitando-nos refletir sobre o processo de exclusão dessas populações de áreas que lhes pertencem por direito, problema este que tendia a se agravar com a Transamazônica (GOTTWALD JUNIOR, 2016, p. 21; COIMBRA, 2009, p. 94).

Na produção de Roberto Farias, bem como na de Glauber Rocha, a violência opera tanto no sentido de ação, praticada pelos algozes da ditadura através das sessões de torturas contra Jofre, como de reação, em que as vítimas de um Estado ditatorial são estimuladas a envolver-se na luta armada, influenciadas, certamente, em revoluções como as ocorridas na China (1949) e em Cuba (1959). Por este ângulo, relacionamos Paulo Martins, de Terra, a Miguel, de Pra Frente, cujos percursos se assemelham, ao escolherem a luta com uso de armas, e se distanciam. Às diferenças, apontamos o fato de que a luta armada no filme de 1967 aparece como uma solução e se encerra nisso; no de 1982, dialogando com o ano de 1970 no Brasil, no qual a trama se desenvolve, a resistência armada está em seu apogeu - observamos isso com o 
Para trás e entre transes: o Brasil entre Iracemas e cabras marcados à morte ou sobre uma análise fílmica de obras censuradas no decurso da ditadura militar

envolvimento de Mariana, companheira de Miguel, na luta -, mas demonstrando os primeiros sinais de fracasso mediante as ações do governo Médici, junto a empresários ${ }^{24}$ que as financiavam, como a criação, em 1969, da Operação Bandeirante (Oban) a fim de combater o que se denominava terrorismo (GASPARI, 2014c, p. 61).

$\mathrm{Na}$ cena em que Mariana tenta convencer seu companheiro da proposta de se exilarem esta questão fica clara, em vista de seu tom frustrado de que em outro momento eles poderiam voltar para o Brasil e tentar mudar tudo sem o perigo de morrer. Assim, se o ano de 1970 foi caracterizado por ser um período de sequestros executados por guerrilheiros (SKIDMORE, 1988, p. 233; GASPARI, 2014b, p. 239), Pra Frente denota que tais atos intitulados subversivos eram igualmente praticados pelos militares, como fica patente por meio do sequestro de Jofre. Mais que isso, tais ações conviviam com a alegria da população diante dos jogos da seleção brasileira no México, como observamos durante todo o filme por meio da alternância entre um Brasil verde e amarelo que estava indo para frente, mediante o futebol; e o outro, para trás, que se tentava esconder através da censura à imprensa, encharcado de sangue ${ }^{25}$.

\footnotetext{
${ }^{24}$ No filme, o Dr. Geraldo Braulen, chefe da empresa onde os irmãos Jofre e Miguel trabalham, aparece como um desses empresários. Este personagem, com algumas diferenças, nos remete ao empresário dinamarquês Henning Albert Boilesen, importante financiador da tortura a dissidentes políticos ou considerados enquanto tais. Cumpre ressaltar que Boilesen também foi responsável por trazer para o Brasil um aparelho que dava choques elétricos, a pianola Boilesen e o microfone Boilesen, em que, de acordo com Kushnir (2004, p. 294),"este último produzia na pessoa uma autotortura, já que a própria voz comandava a intensidade do choque". Cf. idem, Guedes (2016).

${ }^{25}$ Este paradoxo pode ser visto claramente na cena final do filme em que se alternam cenas de comemoração com a conquista do tricampeonato brasileiro, de um lado; de outro, imagens de sofrimento com as mortes de Mariana e um companheiro de militância.
} 


\section{artigos}

\section{Gabriel Bandeira Alexandre}

O documentário de Coutinho nos oferece uma discussão sobre violência que remonta ao período pré-1964, através do assassinato de João Pedro, e que durante a ditadura se fortificou, como reparamos nos relatos dos personagens, nas vozes em off e em imagens de matérias de jornais. Neste sentido, Cabra é especialmente constituído de discursos sobre a perseguição e repressão sofridas pelos camponeses envolvidos no processo de produção do filme. Entretanto, este não é o único motivo pelo qual essas pessoas foram violentadas, haja vista que: i) elas estavam associadas às Ligas Camponesas e, portanto, à luta pela reforma agrária - esta utilizada como uma das justificativas para o Golpe e a ditadura militar, pois a associavam ao comunismo, inimigo central da ditadura militar e seus aliados; e que ii) antes mesmo da instauração da ditadura a vida desses indivíduos estava marcada pela falta de acesso a recursos materiais básicos, conduzindo-nos a um dos sentidos de violência proposto por Stoppino, pontuado no início deste tópico.

Em uma das cenas, aparece o camponês João Virgínio relatando as torturas pelas quais foi submetido na prisão, onde cumpriu 6 dos 10 anos e 6 meses de sua condenação. Em outra, Elizabeth Teixeira, em março de 1964, anuncia “Tem gente lá fora!", indicando a vinda dos que mataram seu marido, e Coutinho utilizou tal cena, sob uma simbologia diferente do sentido das primeiras filmagens, como uma maneira de demonstrar no documentário que a camponesa estava referindo-se aos militares que estavam chegando para interromper as filmagens. Nessa lógica metalinguística, a matriarca é convertida na comunicadora da violência que não mais interromperia a vida de seu marido mas que, de outro modo, impediria o processo de realização do filme cuja participação era o cerne de toda a história.

Assim, embora do gênero documentário, Cabra aproxima-se de Pra Frente, sobretudo no que concerne à denúncia da tortura enquanto uma das formas de 


\section{artigos}

Para trás e entre transes: o Brasil entre Iracemas e cabras marcados à morte ou sobre uma análise fílmica de obras censuradas no decurso da ditadura militar

violência utilizadas pelo Estado militarizado - seja através de relatos (João, em Cabra), seja através de imagens representando-a (Jofre, em Pra Frente) -, cuja existência não esteve circunscrita ao pós-Al-5, como observamos na fala de Virgínio, sugerindo um questionamento acerca da periodização dos anos de chumbo (1968-1974), tendo em vista que desde 1964 a ditadura, por meio de seus agentes, censurava, vigiava, perseguia, torturava e matava.

À luz das análises fílmicas efetuadas acima, sublinhamos, portanto, a importância de tais obras por contribuírem para a demonstração de uma das formas pelas quais os opositores à ditadura, inseridos no campo cultural, executaram sua resistência diante de tal regime. Neste sentido, o cinema, através de cineastas como Glauber, Eduardo, Jorge, Orlando e Roberto, produziu filmes que servem para compreendermos que, a despeito do Estado ditatorial e seus adeptos terem se empenhado na tarefa de coibir o dissenso, a cultura de oposição, como indica-nos Napolitano, não deixou de pulsar nem parou de criticar o regime (NAPOLITANO, 2017, p. 118).

\section{Considerações finais}

Suscetíveis de serem utilizados nas pesquisas históricas, demonstramos a importância dos filmes serem analisados a partir da sua relação com o contexto em que foram produzidos, bem como a quem os produziu, o que conduz-nos, pois, a considerá-los, como qualquer documento histórico, fontes construídas mediante diferentes interesses, como os econômicos, os ideológicos e os políticos. À luz disso, as análises fílmicas aqui realizadas motivaram-nos a depreender como o campo 


\section{artigos}

\section{Gabriel Bandeira Alexandre}

cinematográfico brasileiro se relacionou à sociedade e ao processo de politização na área cultural que, no decurso da ditadura militar, é reconhecido por sua ação de resistência a tal regime.

Neste aspecto, nosso estudo destacou cinco cineastas com posicionamentos dissonantes aos dos partidários da ditadura, sejam eles militares, sejam eles civis. Dessa forma, a partir da relação entre as categorias analíticas Democracia e Violência, e as obras de Glauber Rocha, Eduardo Coutinho, Roberto Farias e Jorge Bodanzky e Orlando Senna, compreendemos a conexão que tais produções mantêm entre si mesmas, assim como com questões fundamentais à época, cuja discussão, não podendo ser realizada de qualquer modo, precisava adequar-se aos discursos oficiais, os quais tencionavam propagandear positivamente a estrutura ditatorial.

Assim, salientamos que: i) os problemas representados pelos filmes analisados ainda permanecem atuais em nossa sociedade, embora diferentemente de períodos anteriores, vide a presença das desigualdades sociais e das violências, além da não conclusão da rodovia Transamazônica/BR-230. É neste sentido que, por vezes, deparamo-nos com afirmações que deslocam as películas de seus devidos contextos de produção, ancoradas na ideia de que alguns cineastas estão à frente de seu tempo; quando, efetivamente, nosso presente é que ainda assemelha-se ao passado, no qual problemáticas não solucionadas garantem a atualidade de obras como Terra em Transe, Iracema, uma Transa Amazônica, Pra Frente, Brasil e Cabra Marcado Para Morrer.

Associada a tais continuidades, consideramos, por fim, que: ii) apesar da Constituição de 1988 abolir oficialmente a censura ${ }^{26}$, atualmente há manifestações

\footnotetext{
${ }^{26}$ Ver: Inciso IX, do Art. $5^{\circ}$ e o $\S 2^{\circ}$, do Art. 220, da Constituição de 1988. Disponível em: <http://www.planalto.gov.br/ccivil_03/Constituicao/Constituicao.htm>. Acesso em: 27 set. 2019.
} 


\section{artigos}

\section{Para trás e entre transes: o Brasil entre Iracemas e cabras marcados à morte ou sobre uma análise fílmica de obras censuradas no decurso da ditadura militar}

desta prática em casos que envolvem não só filmes, mas também livros e exposições de $\operatorname{arte}^{27}$, sendo as redes sociais importantes aliadas nesse processo. A partir de tal questão, evoquemos a ideia de Lucas (2015a, p. 141, 2015b, p. 225, 2015c, p. 10.) e Kushnir $(2004$, p. 35, 63), ao pontuarem a existência de uma cultura censória e cultura da censura na sociedade brasileira ${ }^{28}$, para compreendermos que $\mathrm{o}$ ato de censurar foi, e ainda é, uma realidade, embora violando a legislação corrente. Neste sentido, se antes verificamos a presença da censura baseada em normas censórias; nos dias atuais, por seu turno, tal prática subsiste, contudo sem tais leis, haja vista que as liberdades de expressão e de pensamento são direitos fundamentais constitucionalmente reconhecidos.

\section{${ }^{27}$ Alguns exemplos podem ser conferidos em:}

1) "Cinema sob censura e corte de verbas". Disponível em: <https://www.brasildefato.com.br/2019/10/07/cinema-sob-censura-e-cortes-de-verbas/>. Acesso em: 30 jul. 2019;

2) "Ancine corta apoio a dois filmes sobre LGBTs; produtores acusam censura". Disponível em: $<$ https://www.cartacapital.com.br/politica/ancine-corta-apoio-a-dois-filmes-sobre-lgbts-produtoresacusam-censura/>. Acesso em: 27 set. 2019;

3) "Marcelo Crivella manda censurar HQ dos Vingadores na Bienal do Livro, no Rio". Disponível em: $<$ https://www1.folha.uol.com.br/ilustrada/2019/09/marcelo-crivella-manda-censurar-gibis-dosvingadores-na-bienal-do-livro-no-rio.shtml>. Acesso em: 27 set. 2019;

4) "Queermuseu: O dia em que a intolerância pegou uma exposição para Cristo". Disponível em: <https://brasil.elpais.com/brasil/2017/09/11/politica/1505164425_555164.html>. Acesso em: 27 set. 2019;

E 5.1) "Governo de Rondônia censura clássicos da literatura brasileira e mundial". Disponível em: <https://www.conjur.com.br/2020-fev-06/governo-rondonia-censura-classicos-literatura>. Acesso em: 03 mar. 2020; 5.2) "Censura de livros expõe 'laboratório do conservadorismo' em Rondônia". Disponível em: $\quad$ https://brasil.elpais.com/brasil/2020-02-08/censura-de-livros-expoe-laboratorio-doconservadorismo-em-rondonia.html>. Acesso em: 03 mar. 2020.

${ }^{28}$ Compete lembrar que Kushnir, para além do uso do termo cultura da censura (2004, p. 35), também faz uso de cultura censória (2004, p. 63). Lucas, por seu turno, só faz uso do último. 


\section{artigos}

\section{Gabriel Bandeira Alexandre}

É diante de tais distanciamentos e proximidades entre passado e presente que o Brasil passou por transformações insuficientes no sentido de garantir o pleno exercício da democracia. Assim, convivemos em uma sociedade cuja trajetória histórica estimula a conservação de transes políticos, de Iracemas, de cabras marcados para morrer - o que aproxima-nos do conceito de necropolítica ou política/poder da morte proposto pelo filósofo Mbembe (2018, p. 80 ${ }^{29}$ - e de ameaças à Amazônia, mesclando, pois, progressos e regressos, em que a política, ao ser associada à morte, tem sua existência ameaçada.

Tencionamos, para além da análise fílmica, haver demonstrado como a censura, esse mal manifestado sob diversas formas, mina uma acabada execução de qualquer projeto político-democrático. Portanto, esperamos que a leitura deste trabalho tenha incentivado uma reflexão cujo resultado provoque um distanciamento do que, segundo Arendt (1999, p. 167), é a qualidade pela qual as pessoas identificam o mal: a de tentação; e, inversamente, estimule uma aproximação ao imperativo categórico kantiano ${ }^{30}$, o qual defende a necessidade de se pensar antes de qualquer ação, de modo que a minha vontade, moralmente refletida, não ofenda nem prejudique o outro, ou seja, que ela possa ser transformada em uma norma universal (KANT, 2007, p. 59) o que inviabiliza a possibilidade de existência do ato de censurar, enquanto instituição, em uma sociedade que se pretende democrática.

\footnotetext{
${ }^{29}$ Mbembe (2018, p. 80) afirma que utiliza "a noção de necropolítica e de necropoder para dar conta das várias maneiras pelas quais, em nosso mundo contemporâneo, as armas de fogo são dispostas com o objetivo de provocar a destruição máxima de pessoas e criar 'mundos de morte', formas únicas e novas de existência social, nas quais vastas populações são submetidas a condições de vida que lhes conferem o estatuto de 'mortos-vivos"'.

${ }^{30}$ Conforme Kant, "o imperativo categórico é, portanto, só um único, que é este: Age apenas segundo uma máxima tal que possas ao mesmo tempo querer que ela se torne lei universal". Para tanto, cf. KANT (2007, p. 59).
} 


\section{artigos}

Para trás e entre transes: o Brasil entre Iracemas e cabras marcados à morte ou sobre uma análise fílmica de obras censuradas no decurso da ditadura militar

\section{Referências}

\section{Arquivos de censura}

Certificado $n^{\circ}$ A - 13706, de 6 de novembro de 1984. Departamento de Polícia Federal

- Divisão de Censura de Diversões Públicas (DPF/DCDP).

Elaboração Portaria de 19 de abril de 1967. Ministério da Justiça e Negócios Interiores - Departamento Federal de Segurança Pública (AN/DF).

Parecer 13408/74, de 4 de março de 1974. Ministério da Justiça - Divisão de Censura de Diversões Públicas. (AN/DF).

Parecer do filme Terra em Transe de 18 de abril de 1967. Ministério da Justiça e Negócios Interiores - Departamento Federal de Segurança Pública (AN/DF).

Portaria n 16/67, de 19 de abril de 1967. Ministério da Justiça e Negócios Interiores Departamento Federal de Segurança Pública/Serviço de Censura de Diversões Públicas (NA/DF).

\section{Filmes}

CABRA marcado para morrer. Direção de Eduardo Coutinho. Rio de Janeiro: CPC da UNE; MPC; Mapa, 1984. 


\section{artigos}

\section{Gabriel Bandeira Alexandre}

IRACEMA: uma transa amazônica. Direção de Jorge Bodanzky e Orlando Senna. São Paulo: Stopfilm Ltda.; Jorge Roberto Bodanzky; ZDF, 1974.

PRA FRENTE, Brasil. Direção de Roberto Farias. Rio de Janeiro: Produções Cinematográficas R. F. Farias Ltda.; Embrafilme, 1982.

TERRA em transe. Direção de Glauber Rocha. Rio de Janeiro: Mapa Produções Cinematográficas Ltda, 1967.

Jornal

DIARIO DE PERNAMBUCO, Recife, n. 79 - ano 139, de 7 de abril de 1964. Disponível em: <http://bndigital.bn.gov.br/hemeroteca-digital/>. Acesso em: 13 out. 2019.

\section{Legislação}

BRASIL. Ato Institucional $n^{\circ}$ 5, de 13 de dezembro de 1968. São mantidas a Constituição de 24 de janeiro de 1967 e as Constituições Estaduais; O Presidente da República poderá decretar a intervenção nos estados e municípios, sem as limitações previstas na Constituição, suspender os direitos políticos de quaisquer cidadãos pelo prazo de 10 anos e cassar mandatos eletivos federais, estaduais e municipais, e dá outras providências. Diário Oficial da União, Brasília, DF, 13 dez. 1968. Disponível em: <http://www.planalto.gov.br/ccivil_03/AIT/ait-05-68.htm>. Acesso em: 13 out. 2019.

BRASIL. Constituição (1967). Constituição da República Federativa do Brasil. Brasília, DF: Senado, $1967 . \quad$ Disponível em: <http://www.planalto.gov.br/ccivil_03/constituicao/constituicao67.htm>. Acesso em: 13 out. 2019.

BRASIL. Constituição (1988). Constituição da República Federativa do Brasil. Brasília, DF: Senado, $1988 . \quad$ Disponível em: <http://www.planalto.gov.br/ccivil_03/Constituicao/Constituicao.htm>. Acesso em: 27 set. 2019. 


\section{artigos}

Para trás e entre transes: o Brasil entre Iracemas e cabras marcados à morte ou sobre uma análise fílmica de obras censuradas no decurso da ditadura militar

BRASIL. Lei $n^{\circ} 5.536$, de 21 de novembro de 1968. Dispõe sobre a censura de obras teatrais e cinematográficas, cria o Conselho Superior de Censura, e dá outras providências. Diário Oficial da União, Brasília, DF, 22 nov. 1968. Seção 1. Disponível em: $\quad$ <https://www2.camara.leg.br/legin/fed/lei/1960-1969/lei-5536-21-novembro1968-357799-publicacaooriginal-1-pl.html>. Acesso em: 28 jul. 2019.

\section{Referências Bibliográficas}

ALBIN, Ricardo Cravo. Driblando a censura: de como o cutelo vil incidiu na cultura. Rio de Janeiro: Gryphus, 2002.

ARENDT, Hannah. Eichmann em Jerusalém: um relato sobre a banalidade do mal. São Paulo: Companhia das Letras, 1999.

BARROS, José D'Assunção. História Comparada - da contribuição de Marc Bloch à constituição de um moderno campo historiográfico. História Social, Campinas - SP, $\mathrm{n}^{\circ}$ 13, p. 7-21, 2007.

BARROS, José D’Assunção. Posfácio - ao lado da História Comparada: Histórias Interconectadas, Histórias Cruzadas e outras histórias. In: ALVES, Gracilda; LAPSKY, Igor; SCHURSTER, Karl (Orgs.). História comparada: debates teóricos e metodológicos. Recife: Edupe, Editora da Universidade de Pernambuco, 2013. p. 156-179.

BERG, Creuza de Oliveira. Mecanismos do silêncio: expressões artísticas e censura no regime militar (1964-1984). São Carlos: EdUFSCar, 2002.

BLOCH, Marc. Comparação. In: BLOCH, Marc. História e Historiadores. Lisboa: Teorema, 1998. p. 111-118.

BOBBIO, Norberto. Dicionário de política. Brasília: Editora Universidade de Brasília, 1998. 


\section{artigos}

\section{Gabriel Bandeira Alexandre}

BRESCIANI, Stella. Prefácio: Um tema difícil, uma reflexão ousada. In: KUSHNIR, Beatriz. Cães de guarda: Jornalistas e censores, do Al-5 à Constituição de 1988. São Paulo: Boitempo Editorial, 2004. p. 11-14.

COIMBRA, Marcos da Silva; COUTINHO, Eduardo de Faria. Do livro ao filme: uma trajetória de Iracema. Ipotesi, Juiz de Fora, v. 13, n. 1, p. 89-101, jan./jul. 2009.

DIAS JUNIOR, J. E. S. IRACEMA UMA TRANSAMAZÔNICA: O Filme como História, In: XXVII Simpósio Nacional de História: Conhecimento Histórico e Diálogo Social, 2013, Natal RN. Conhecimento Histórico e Diálogo Social, v. 1, 2013, p. 1-15.

DREIFUSS, René Armand. 1964: a conquista do Estado: Ação Política, Poder e Golpe de Classe. Petrópolis: Vozes, 1981.

FERRO, Marc. Cinema e História. Rio de Janeiro: Paz e Terra, 1992.

FICO, Carlos. O golpe de 64: momentos decisivos. Rio de Janeiro: Editora FGV, 2014.

GASPARI, Elio. A ditadura derrotada. Rio de Janeiro: Intrínseca, 2014a.

GASPARI, Elio. A ditadura envergonhada. Rio de Janeiro: Intrínseca, 2014b.

GASPARI, Elio. A ditadura escancarada. Rio de Janeiro: Intrínseca, 2014c.

GOTTWALD JUNIOR, Luis Alberto. A desconstrução do mito da Transamazônica a partir da ótica cinematográfica: tradições intelectuais e representações de Jorge Bodanzky e Orlando Senna, no filme Iracema: Uma Transa Amazônica. 161f. Dissertação (Mestrado em História, Cultura e Identidades) - Universidade Estadual De Ponta Grossa, Ponta Grossa, 2016.

GUEDES, Wallace Andrioli. Política como produto: Pra frente Brasil e o cinema de Roberto Farias. 317f. Tese (Doutorado) - Universidade Federal Fluminense, Instituto de Ciências Humanas e Filosofia. Departamento de História, 2016.

HARRIS, Hugo de Almeida. Cabra marcado para morrer: mosaico de fragmentos no documentário de Eduardo Coutinho. 110f. Dissertação (Mestrado em Comunicação) Pontifícia Universidade Católica de São Paulo, São Paulo, 2008. 


\section{artigos}

Para trás e entre transes: o Brasil entre Iracemas e cabras marcados à morte ou sobre uma análise fílmica de obras censuradas no decurso da ditadura militar

KANT, Immanuel. Fundamentação da Metafísica dos Costumes. Lisboa: Edições 70, Lda, 2007.

KOSELLECK, Reinhart. Futuro passado: contribuição à semântica dos tempos históricos. Rio de Janeiro: Contraponto: Ed. PUC-Rio, 2006.

KUSHNIR, Beatriz. Cães de guarda: Jornalistas e censores, do Al-5 à Constituição de 1988. São Paulo: Boitempo Editorial, 2004.

LUCAS, Meize Regina de Lucena. A tessitura dos fios de Ariadne: arquivo e censura cinematográfica no Brasil. Antíteses, Londrina, v.8, n. 15, p. 134-153, jan./jun. 2015a.

LUCAS, Meize Regina de Lucena. Cinema e censura no Brasil: uma discussão conceitual para além da ditadura. Projeto História, São Paulo, n. 52, p. 220-244, jan.-abr. 2015b.

LUCAS, Meize Regina de Lucena. Usos do passado: entre a censura e a representação no cinema brasileiro. Revista Em Perspectiva, v. 1, n. 1, p. 7-26, 2015 c.

MBEMBE, Achille. Necropolítica: biopoder, soberania, estado de exceção, política da morte. São Paulo: n-1 edições, 2018.

NAPOLITANO, Marcos. 1964: História do Regime Militar Brasileiro. São Paulo: Contexto, 2017.

NAPOLITANO, Marcos. Fontes audiovisuais: a história depois do papel. In: PINSKY, Carla Bassanezi (org.). Fontes Históricas. São Paulo: Contexto, 2008. p. 235-289.

PADULA LAMAS, C. T.; REIS JUNIOR, A.; História, Cinema e Censura: Silenciamentos e resistência em Pra frente Brasil, de Roberto Farias. Lumina, Juiz de Fora, v. 8, n. 2, p. 1 24, 27 jan. 2015.

PINTO, Leonor E. Souza. (Des)caminhos da censura no cinema brasileiro: os anos de ditadura. 2005. 
Gabriel Bandeira Alexandre

$<$ http://www.memoriacinebr.com.br/Textos/Des_caminhos_da_censura.pdf $>$. Acesso em: jul. 2019.

PINTO, Leonor E. Souza. Memória da Censura no Cinema Brasileiro: 1964-1988. Disponível em: <http://memoriacinebr.com.br/>. Acesso em: 2018.

PINTO, Leonor E. Souza. O cinema brasileiro face à censura imposta pelo regime militar no Brasil - 1964/1988. 2006. Disponível em: $<$ http://www.memoriacinebr.com.br/textos/o_cinema_brasileiro_face_a_censura.pdf $>$. Acesso em: jul. 2019.

QUEIROZ, Anne Lee Fares de. Cabra marcado para morrer: da história do cabra à história do filme. Dissertação (Mestrado) - Universidade Estadual de Campinas, Instituto de Artes, Campinas, SP, 2005.

RIDENTI, Marcelo. Cultura. In: REIS, Daniel Aarão (Coordenação). Modernização, ditadura e democracia: 1964-2010. Rio de Janeiro: Objetiva, 2014. p. 233-283.

ROCHA, Glauber. Revolução do Cinema Novo. Rio de Janeiro: Alhambra/Embrafilme, 1981.

ROSENSTONE, Robert A. A história nos filmes, os filmes na história. Rio de Janeiro: Paz e Terra, 2015.

SILVA, Kalina Vanderlei. Dicionário de conceitos históricos. São Paulo: Contexto, 2009.

SIMÕES, Inimá. Roteiro da Intolerância: a censura cinematográfica no Brasil. São Paulo: Editora SENAC São Paulo, 1999.

SKIDMORE, Thomas E. Brasil: de Castelo a Tancredo, 1964-1985. Rio de Janeiro: Paz e Terra, 1988.

STOPPINO, Mario. Violência. In: BOBBIO, Norberto. Dicionário de política. Brasília: Editora Universidade de Brasília, 1998. p. 1291-1298. 


\section{artigos}

Para trás e entre transes: o Brasil entre Iracemas e cabras marcados à morte ou sobre uma análise fílmica de obras censuradas no decurso da ditadura militar

VIANA, Irma. Arte política e a tarefa do intelectual em Terra em Transe. Baleia na Rede, vol. 1, no 8, ano VIII, p. 1-14, dez/2011.

XAVIER, Ismail. O cinema brasileiro moderno. São Paulo: Paz e Terra, 2001. 